\title{
Geochemical Assessment and Spatial Analysis of Heavy Metals in the Surface Sediments in the Eastern Beibu Gulf: A Reflection on the Industrial Development of the South China Coast
}

\author{
Fajin Chen ${ }^{1,2}{ }^{(1)}$, Jing Lin ${ }^{3,4}$, Bihua Qian ${ }^{4,5}$, Zhai Wu ${ }^{4}$, Peng Huang ${ }^{2,4}$, Kai Chen ${ }^{6}$, Tianyao Li ${ }^{4}$ \\ and Minggang Cai ${ }^{4,6, *}$ \\ 1 Guangdong Province Key Laboratory for Coastal Ocean Variation and Disaster Prediction, Guangdong \\ Ocean University, Zhanjiang 524088, China; fjchen04@163.com \\ 2 College of Ocean and Meteorology, Guangdong Ocean University, Zhanjiang 524088, China; \\ penghuang@xmu.edu.cn \\ 3 Third Institution of Oceanography, State Oceanic Administration, Xiamen 361005, China; linjing@tio.org.cn \\ 4 College of Ocean and Earth Sciences, Xiamen University, Xiamen 361102, China; qbh40@126.com (B.Q.); \\ 22320151152094@stu.xmu.edu.cn (Z.W.); 22320142200993@stu.xmu.edu.cn (T.L.) \\ 5 Marine Environment and Fishery Monitoring Station of Quanzhou, Quanzhou 362000, China \\ 6 Coastal and Ocean Management Institute, Xiamen University, Xiamen 361102, China; \\ kaychen@stu.xmu.edu.cn \\ * Correspondence: mgcai@xmu.edu.cn; Tel.: +86-592-218-6188
}

Received: 10 February 2018; Accepted: 10 March 2018; Published: 12 March 2018

\begin{abstract}
The Beibu Gulf (also named the Gulf of Tonkin), located in the northwest of the South China Sea, is representative of a bay suffering from turbulence and contamination associated with rapid industrialization and urbanization. In this study, we aim to provide the novel baseline levels of heavy metals for the research area. Concentrations of five heavy metals (i.e., $\mathrm{Cu}, \mathrm{Pb}, \mathrm{Zn}, \mathrm{Cd}$ and $\mathrm{Cr}$ ) were determined in surface sediments from 35 sites in the eastern Beibu Gulf. The heavy metal content varied from 6.72 to $25.95 \mathrm{mg} / \mathrm{kg}$ for $\mathrm{Cu}, 16.99$ to $57.98 \mathrm{mg} / \mathrm{kg}$ for $\mathrm{Pb}, 73.15$ to $112.25 \mathrm{mg} / \mathrm{kg}$ for $\mathrm{Zn}$, 0.03 to $0.12 \mathrm{mg} / \mathrm{kg}$ for Cd, and 20.69 to $56.47 \mathrm{mg} / \mathrm{kg}$ for Cr, respectively. With respect to the Chinese sediment quality criteria, sediments in the eastern Beibu Gulf have not been significantly affected by coastal metal pollutions. The results deduced from the geoaccumulation index $\left(\mathrm{I}_{\text {geo }}\right)$ showed that the study area has been slightly polluted by $\mathrm{Pb}$, which might be caused by non-point sources. Relatively high concentrations of $\mathrm{Cu}, \mathrm{Pb}$ and $\mathrm{Cd}$ were found around the coastal areas of Guangxi province, the Leizhou Peninsula and the northwest coast of Hainan Island, whereas the highest concentrations of $\mathrm{Zn}$ and $\mathrm{Cr}$ were found on the northwest coast of Hainan Island. Spatial distribution patterns of the heavy metals showed that bioavailable fractions of $\mathrm{Pb}$ were higher than in the residual fractions, while $\mathrm{Cu}$ and $\mathrm{Cd}$ concentrations in exchangeable and carbonate fractions were relatively higher than those in the bioavailable fractions. Hierarchical clustering analysis suggested that the sampling stations could be separated into three groups with different geographical distributions. Accompanying their similar spatial distribution in the study area, significant correlation coefficients among $\mathrm{Cu}, \mathrm{Cd}$ and $\mathrm{Pb}$ were also found, indicating that these three metals might have had similar sources. Overall, the results indicated that the distribution of these heavy metals in the surface sediments collected from the Beibu Gulf was complex.
\end{abstract}

Keywords: heavy metals; assessment; distribution; surface sediments; eastern Beibu Gulf 


\section{Introduction}

The Beibu Gulf (i.e., Gulf of Tonkin), located in the northwest of the South China Sea (SCS), is representative of a tropical sea regime that is significantly affected by the monsoon. Beibu Gulf is a very important area for the economic progress of nearby countries (e.g., China and Vietnam), and it is considered as a traditional fishing ground because of its high productivity and rich biological diversity. As the largest area of extant mangrove and sea grass in China, the Beibu Gulf is also a main source of fishery products for coastal cities, such as clam, crabs and varieties of fishes [1-4]. Therefore, it is a significant fishery and has also become the largest free trade area in South China $[5,6]$. However, during recent decades there has been high speed economic development and urban construction in the cities surrounding the eastern Beibu Gulf. The Beibu Gulf Economic Zone, which was established in 2008, has promoted economic activity. For example, total production increased at a rate of $15.6 \%$ in 2010 [7]. Meanwhile, industries such as equipment production, petroleum processing and metal smelting—specifically Qinzhou's oil refining projects and Fangcheng Port's metal industries-have been developing rapidly [7]. The development of the Beibu Gulf Economic Zone results in the emission of large amounts of discharged materials into the Beibu Gulf via river input and atmospheric deposition. Heavy metals are usually treated as one of the most serious pollutants due to their potentially toxic effects, environmental persistence and bioaccumulation capacity [8-11]. Heavy metal pollution in aquatic environments has received much attention in China in the past decade [6,12-16]. With economic development and urbanization, the estuaries and coastal ecosystems in China are now facing increasingly heavy metal pollution stress. It was reported that $29,720 \mathrm{~km}^{2}$ of offshore areas of China were heavily polluted, and about 30,000 $\mathrm{t}$ of metals were discharged into the coastal environment by major rivers every year between 2002 and 2008 [17].

Heavy metals that have natural and anthropogenic sources are introduced into coastal areas and thereby possibly impact marine organisms by several pathways, including river runoff, atmospheric deposition, and industrial and agricultural activities [18-20]. There are some rivers in the south of Guangxi, the southwest of Guangdong, and western Hainan Island, that carry industrial, agricultural, and urban domestic wastewater into the eastern Beibu Gulf. In addition, seawater in the eastern Beibu Gulf may also be influenced by discharge from the Pearl River that runs through the Qiongzhou Strait [21]. Metals in aquatic ecosystems can also be adsorbed on suspended particles which then settle onto surface sediments [22]. That is to say, sediments are regarded as both sinks and potential secondary sources of heavy metals, and play an important role in the geochemical behavior of heavy metals [23,24].

Although there have been reports about some heavy metals in the local region of the Beibu Gulf, most of the focus has been on the near-shore sites and some targeted regions around oil platforms [25]. There were seldom results indicating heavy metals in the sediments for the areas that were relatively open sea. These studies were mainly conducted since 2010, and focused on the distribution of metals, background values, and historical records. Only one study reports on metals in sediments for the entire eastern Beibu Gulf. Our study could fill the gap in providing data on the heavy metal content of marine sediments in a marginal sea of China. The objectives of this work were to determine and evaluate the heavy metals content in the surface sediments from the eastern Beibu Gulf, secondly, to discuss their distribution patterns and possible sources, and thirdly to assess the sedimentological factors that affect their distribution.

\section{Materials and Methods}

\subsection{Study Area and Sample Collection}

The Beibu Gulf (17.0 22.0 N, 105.5 110.0 E) is a semi-enclosed gulf located in the northwest of the South China Sea (SCS). The depth of the Gulf ranges from 10 to $60 \mathrm{~m}$, with a mean value of $38 \mathrm{~m}$. It has an area of approximately $128,000 \mathrm{~km}^{2}$ [26], and connects to the SCS through a narrow ocean 
channel (the Qiongzhou Strait) to the east and between Hainan Island and the Vietnamese coast to the south (Figure 1).

Marine surface sediment samples were collected from 35 stations in the eastern Beibu Gulf in October 2007 (Figure 1). These stations have good coverage of the study area. Surface sediment samples (to a depth of $3 \mathrm{~cm}$ ) were taken with a grab sampler. Sediment samples were removed from the sampler using a plastic spoon, then placed into acid-washed plastic bags and stored at $-4{ }^{\circ} \mathrm{C}$ before processing and analyzing.

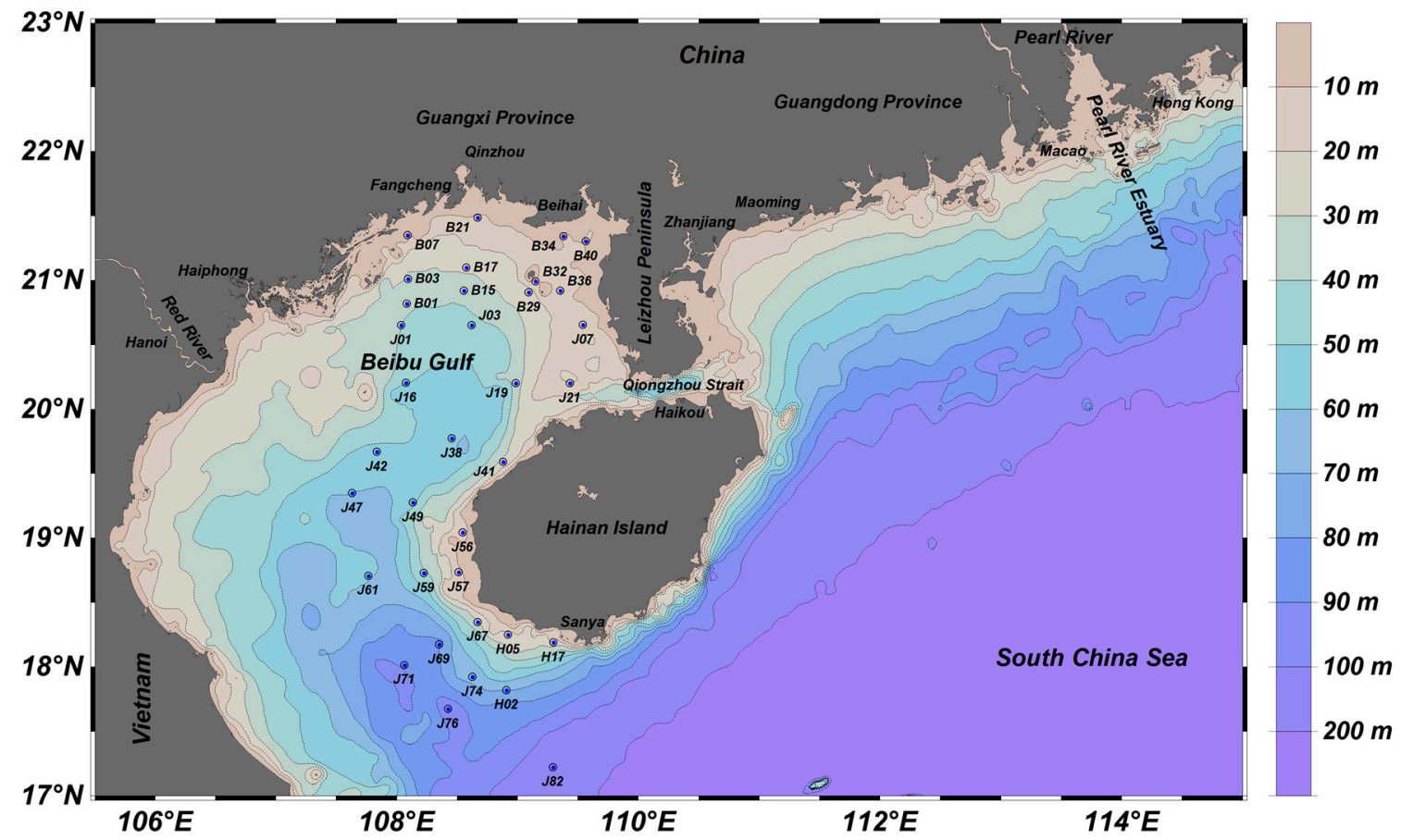

Figure 1. Sampling stations for surface sediments in the Beibu Gulf.

\subsection{Sample Pretreatment and Analysis}

Sediment samples were freeze-dried for at least $24 \mathrm{~h}$ and then ground to pass through a 160 mesh sieve using an agate mortar and pestle. For metal analysis, samples were digested with the mixture of $\mathrm{HNO}_{3}$ and $\mathrm{HClO}_{4}$ as described by Cai [27]. Samples were then examined for $\mathrm{Cu}, \mathrm{Pb}, \mathrm{Zn}, \mathrm{Cd}$ and $\mathrm{Cr}$ concentrations using an atomic absorption spectrophotometer (SOLAAR M6, Thermo Fisher Scientific, Waltham, MA, USA). Redox potential (Eh) was recorded in situ using a potentiometer. Granulometry was determined using a Mastersizer 2000 laser particle size analyzer. Organic carbon was measured based on potassium dichromate oxidation-ferrous sulphate titrimetry and sulfide was measured by iodimetry.

\subsection{Quality Control}

Ultrapure water was used throughout the study. All glassware was previously soaked in nitric acid (1:3) for at least 7 days and then rinsed with ultrapure water. Method blanks were prepared with each batch of digestions. The detection limits were calculated by 11 determinations of the whole Program Blank Value. For precision, samples were analyzed using six replicates. The accuracy of the analyzed method was checked using certified reference material (GSW-07314) which is offshore marine sediment. The results for each heavy metal shown in Table 1 indicate a good agreement between the measured and assigned values. Only in the case of $\mathrm{Pb}$ was the measured value slightly lower than the assigned value. The relative standard deviations were lower than $6 \%$ for all metals. 
Table 1. Measured and certified values of metal concentrations in standard reference material.

\begin{tabular}{cccccc}
\hline Element & $\begin{array}{c}\text { Method Blank } \\
(\boldsymbol{\mu g} / \mathbf{L})\end{array}$ & $\begin{array}{c}\text { Limit of Detection } \\
(\boldsymbol{\mu g} / \mathbf{L})\end{array}$ & $\begin{array}{c}\text { Relative Standard } \\
\text { Deviation } \mathbf{( \% )}\end{array}$ & $\begin{array}{c}\text { Measured Value } \\
(\mathbf{m g} / \mathbf{k g})\end{array}$ & $\begin{array}{c}\text { Assigned Value } \\
(\mathbf{m g} / \mathbf{k g})\end{array}$ \\
\hline $\mathrm{Cu}$ & 1.23 & 0.04 & 1.6 & $27.00 \pm 0.60$ & $28 \pm 2$ \\
$\mathrm{~Pb}$ & 5.47 & 0.21 & 2.6 & $16.40 \pm 0.60$ & $23 \pm 4$ \\
$\mathrm{Zn}$ & 7.00 & 1.41 & 1.2 & $80.10 \pm 1.29$ & $77 \pm 6$ \\
$\mathrm{Cd}$ & 0.017 & 0.009 & 5.3 & $0.21 \pm 0.015$ & $0.17 \pm 0.04$ \\
$\mathrm{Cr}$ & 2.60 & 0.08 & 0.9 & $46.2 \pm 0.52$ & $46 \pm 8$ \\
\hline
\end{tabular}

\subsection{Geoaccumulation Index}

In order to better understand the current environmental status and metal contamination in the eastern Beibu Gulf, the geoaccumulation index $\left(\mathrm{I}_{\text {geo }}\right)$ was calculated to assess the extent of sediment contamination in the study area. It was originally defined in 1979 [28] and can be calculated using the following expression:

$$
\mathrm{I}_{\text {geo }}=\log _{2}\left[\frac{\mathrm{C}_{\mathrm{n}}}{1.5 * \mathrm{~B}_{\mathrm{n}}}\right] \text {, }
$$

where $C_{n}$ is the measured content of the examined metal " $n$ " in the sediment; $B_{\mathbf{n}}$ is the geochemical background content of the metal " $\mathrm{n}$ ", and factor 1.5 is the background matrix correction factor for lithogenic effects.

\section{Results and Discussion}

\subsection{Granulometry and General Characteristics}

As shown in Figure 2, the contents of organic carbon and sulfide varied from $0.03 \sim 0.79 \%$ and $2.5 \sim 71.6 \mathrm{mg} / \mathrm{kg}$, with the highest levels at station B21 which is located in the coastal zone of Guangxi Province. The results showed that the mean content of clay (grain size: 0.01-3.9 $\mu \mathrm{m}$ ) for all sediment samples was $16.89 \%$, with a range of $6.36 \%$ to $29.72 \%$, and the values of the Eh ranged from -150 to 142. In the northernmost portion of study area, the weathering rock from surrounding land maybe influences the distribution of clay, organic carbon and sulfide [29]. The high concentrations of organic carbon and sulfide present in the coastal zone indicated that these are mainly terrigenous inputs, such as plant detritus from mangroves [3].

\subsection{Concentrations of Heavy Metals in the Sediments}

The concentrations of the five heavy metals in the surface sediments from the eastern Beibu Gulf varied from 6.72 to $25.95 \mathrm{mg} / \mathrm{kg}$ for $\mathrm{Cu}, 16.99$ to $57.98 \mathrm{mg} / \mathrm{kg}$ for $\mathrm{Pb}, 73.15$ to $112.25 \mathrm{mg} / \mathrm{kg}$ for $\mathrm{Zn}$, 0.03 to $0.12 \mathrm{mg} / \mathrm{kg}$ for $\mathrm{Cd}$ and 20.69 to $56.47 \mathrm{mg} / \mathrm{kg}$ for Cr.

The results obtained from our study were compared with those from other regions in the world (Table 2). The average concentrations of $\mathrm{Pb}$ and $\mathrm{Cd}$ in the eastern Beibu Gulf were significantly higher, while the $\mathrm{Zn}$ concentration was lower, if we compared our data to that gained from the Guangxi province inshore investigated in 1998 [30]. The differences in concentration clearly showed that anthropogenic inputs of $\mathrm{Pb}$ and $\mathrm{Cd}$ have increased in the study area during the past 10 years. The mean values of selected metals were low compared to those from neighboring regions, such as the Pearl River Estuary [31], Pearl River [32] and Victoria Harbour [33], suggesting that heavy metal pollution is not a key issue in the eastern Beibu Gulf at present. In comparison with Taranto Gulf [34] and Thermaikos Gulf [35], the mean concentrations of $\mathrm{Cu}, \mathrm{Pb}, \mathrm{Zn}, \mathrm{Cd}$ and $\mathrm{Cr}$ in the eastern Beibu Gulf were all lower. The concentrations of $\mathrm{Cu}, \mathrm{Zn}, \mathrm{Cd}$ and $\mathrm{Cr}$ were lower than in Puerto Rico [36], while the concentration of $\mathrm{Pb}$ was higher. Furthermore, comparing with Leizhou Bay, the concentrations of $\mathrm{Cu}$, $\mathrm{Cd}$ and $\mathrm{Cr}$ were also lower, while the concentrations of $\mathrm{Pb}$ and $\mathrm{Zn}$ were higher $[37,38]$.

The concentrations of metals in this study were compared with other recent research studying sediments (Table 2) [25,39], which indicated that the concentrations of most metals $(\mathrm{Cu}, \mathrm{Pb}, \mathrm{Cd}, \mathrm{Cr})$ 
were generally increasing from 2007 to 2013. Additionally, concentrations of $\mathrm{Pb}$ and $\mathrm{Cd}$ had obviously increased throughout the different sampling years (2007, 2011 and 2013), which reflects the influence of anthropogenic activities. Some studies have concluded that the metals risk in coastal Guangxi has increased in the past few years due to economic development and urbanization [39]. The eastern Beibu Gulf has been affected by industrial activities, such as petroleum production, printing industries and power plants [39], which increase the metals risk in sediments.

Table 2. Comparison of the concentrations of heavy metals in the study area with values from the literature (unit: $\mathrm{mg} / \mathrm{kg}$ ).

\begin{tabular}{ccccccc}
\hline Study Area & $\mathbf{C u}$ & $\mathbf{P b}$ & $\mathbf{Z n}$ & $\mathbf{C d}$ & $\mathbf{C r}$ & References \\
\hline Eastern Beibu Gulf & 16.37 & 32.23 & 93.12 & 0.08 & 35.51 & This study \\
\hline Beibu Gulf & - & 36.22 & - & 0.12 & - & {$[25]$} \\
\hline Beibu Gulf & 27.07 & 46.56 & 73.6 & 0.16 & 59.50 & {$[39]$} \\
\hline $\begin{array}{c}\text { Coastal sea area, Guangxi } \\
\text { Province, China }\end{array}$ & 18.3 & 19 & - & 0.025 & - & {$[30]$} \\
\hline Pearl River Estuary, China & 46.8 & 47.9 & 140 & - & 87.6 & [31] \\
\hline Pearl River, South China & 348.0 & 102.6 & 383.4 & 1.72 & 93.1 & [32] \\
\hline Victoria Harbour & $45.2-3789.5$ & $47.4-138.1$ & $97.9-610.4$ & $2.61-3.33$ & $57.5-601.2$ & {$[33]$} \\
\hline Taranto Gulf & 47.4 & 57.8 & 102.3 & - & 85.9 & [34] \\
\hline Puerto Rico & 106 & 11 & - & 0.13 & 55 & [35] \\
\hline Leizhou Bay & $4.51-30.5$ & $8.94-32.2$ & - & $0.18-0.67$ & - & [37] \\
\cline { 2 - 7 } & 22 & 21.9 & 60.4 & 0.12 & 60 & [38] \\
\hline Thermaikos Gulf & 80 & 77 & 184 & - & 47 & [35] \\
\hline Primary standard criteria & 35.0 & 60.0 & 150.0 & 0.5 & 80 & a \\
\hline “-": not available; “a”: values from national standard GB 18668-2002 (CSBTS, 2002).
\end{tabular}

\subsection{Assessment of Trace Metal Pollution}

The metal concentrations were examined against the Marine Sediment Quality standard (GB 18668-2002), which was issued by the China State Bureau of Quality and Technical Supervision (CSBTS, 2002) (see Table 2). It has three standard criteria for marine sediments, among which the primary sediment standard criterion is the strictest and is applied to protect marine life habitats that include rare and endangered species, as well as places for human recreation and sports. Our results showed that the concentrations of heavy metals in the sediments from the study area met the primary standard criterion. Therefore, a general conclusion could be drawn that sediments in the eastern Beibu Gulf have not been significantly affected by metal pollution.

Since we did not have background values for metals in sediments from the Beibu Gulf, the $\mathrm{I}_{\text {geo }}$ was calculated using accepted earth crust values [40]. The earth crust values were in $\mathrm{mg} / \mathrm{kg}: 45$ for $\mathrm{Cu}, 20$ for $\mathrm{Pb}, 95$ for $\mathrm{Zn}, 0.3$ for $\mathrm{Cd}$, and 90 for Cr. According to the classification from Müller [41], $\mathrm{I}_{\text {geo }}<0$ is unpolluted, $0-1$ is unpolluted to moderately polluted, $1-2$ is moderately polluted, $2-3$ is moderately to highly polluted, $3-4$ is highly polluted, $4-5$ is highly to very highly polluted, and $>6$ is very highly polluted.

The $\mathrm{I}_{\text {geo }}$ values deduced from the measured data in the study area are listed in Table 3 . The $\mathrm{I}_{\text {geo }}$ values were $-3.33 \sim-1.38$ for $\mathrm{Cu},-0.82 \sim 0.95$ for $\mathrm{Pb},-0.96 \sim-0.34$ for $\mathrm{Zn},-3.91 \sim-1.91$ for $\mathrm{Cd}$ and $-2.71 \sim-1.26$ for $\mathrm{Cr}$, respectively. The $\mathrm{I}_{\text {geo }}$ values of $\mathrm{Cu}, \mathrm{Zn}, \mathrm{Cd}$ and $\mathrm{Cr}$ in all stations were less than zero $\left(\mathrm{I}_{\mathrm{geo}}<0\right)$, indicating that the eastern Beibu Gulf had not been polluted by these metals. In contrast, most stations located in the northeast of the Beibu Gulf had a lower degree of Pb pollution ( $\mathrm{I}_{g e o}=0 \sim 1$ ). The $\mathrm{Pb}$ contamination in the coastal zone of Guangxi Province and northwest of Hainan Island might be caused by non-point sources [42-44]. 
Table 3. Geoaccumulation index ( $\mathrm{I}_{\text {geo }}$ ) values of heavy metals in the eastern Beibu Gulf.

\begin{tabular}{cccccc}
\hline Station & $\mathbf{C u}$ & $\mathbf{P b}$ & $\mathbf{Z n}$ & $\mathbf{C d}$ & $\mathbf{C r}$ \\
\hline B01 & -1.89 & 0.28 & -0.63 & -2.49 & -2.12 \\
B03 & -1.84 & 0.33 & -0.60 & -2.68 & -2.11 \\
B07 & -2.00 & 0.51 & -0.88 & -2.68 & -2.71 \\
B15 & -1.76 & 0.17 & -0.52 & -2.49 & -2.25 \\
B17 & -1.87 & 0.18 & -0.68 & -2.49 & -1.93 \\
B21 & -1.74 & 0.63 & -0.73 & -2.17 & -2.21 \\
B29 & -1.91 & 0.04 & -0.76 & -2.68 & -2.57 \\
B32 & -1.88 & 0.26 & -0.83 & -2.68 & -2.34 \\
B34 & -1.94 & 0.46 & -0.89 & -2.68 & -2.09 \\
B36 & -1.43 & 0.55 & -0.39 & -1.91 & -2.02 \\
B40 & -1.61 & 0.95 & -0.61 & -1.91 & -2.01 \\
H02 & -1.96 & -0.04 & -0.45 & -2.32 & -1.79 \\
H05 & -2.40 & -0.30 & -0.86 & -2.91 & -2.57 \\
H17 & -2.42 & -0.24 & -0.90 & -3.49 & -2.54 \\
J01 & -1.87 & 0.24 & -0.52 & -2.17 & -1.93 \\
J03 & -1.93 & 0.00 & -0.58 & -2.17 & -1.79 \\
J07 & -1.38 & 0.55 & -0.34 & -1.91 & -2.09 \\
J16 & -2.11 & 0.03 & -0.71 & -2.03 & -1.76 \\
J19 & -2.37 & -0.34 & -0.71 & -2.49 & -1.58 \\
J21 & -1.73 & 0.32 & -0.46 & -2.17 & -1.85 \\
J38 & -1.73 & 0.29 & -0.42 & -2.32 & -1.70 \\
J41 & -1.65 & 0.36 & -0.36 & -2.32 & -1.26 \\
J42 & -2.09 & -0.09 & -0.44 & -2.49 & -1.36 \\
J47 & -2.22 & -0.30 & -0.48 & -2.32 & -1.61 \\
J49 & -2.21 & 0.04 & -0.41 & -2.91 & -1.82 \\
J56 & -2.30 & 0.01 & -0.64 & -3.17 & -2.06 \\
J57 & -3.33 & -0.82 & -0.96 & -3.91 & -2.01 \\
J59 & -2.60 & -0.32 & -0.60 & -3.49 & -1.94 \\
J61 & -2.62 & -0.38 & -0.66 & -3.17 & -1.90 \\
J67 & -2.89 & -0.60 & -0.87 & -3.49 & -1.96 \\
J69 & -2.40 & -0.16 & -0.58 & -2.49 & -1.75 \\
J71 & -2.45 & -0.21 & -0.61 & -2.68 & -1.66 \\
J74 & -2.23 & -0.07 & -0.55 & -2.68 & -1.69 \\
J76 & -2.25 & -0.13 & -0.52 & -2.32 & -1.74 \\
J82 & -2.34 & -0.21 & -0.67 & -2.91 & -1.93 \\
\hline & & & & &
\end{tabular}

\subsection{Spatial Distribution Patterns}

As shown in Figure 2, the distributions of $\mathrm{Pb}$ and $\mathrm{Cd}$ were similar to that of $\mathrm{Cu}$, and significant correlations among $\mathrm{Cu}, \mathrm{Pb}$ and $\mathrm{Cd}$ were also found (Table 4). The highest concentrations of $\mathrm{Cu}$ and $\mathrm{Cd}(25.95 \mathrm{mg} / \mathrm{kg}$ and $0.12 \mathrm{mg} / \mathrm{kg}$, respectively) were found in site J07, which is located in the coastal area of Guangxi Province. The maximum Pb concentration at station B40 was $57.98 \mathrm{mg} / \mathrm{kg}$. The levels of $\mathrm{Cu}, \mathrm{Pb}$ and $\mathrm{Cd}$ in surface sediments from the northern Beibu Gulf were higher than those from the south. Alongside $\mathrm{Pb}$, as a result, $\mathrm{Cu}$ and $\mathrm{Cd}$ may also be influenced by anthropogenic activities. The patches with higher concentrations of the above heavy metals were mainly confined to the coastal areas of Guangxi Province, Leizhou Peninsula and the northwest coast of Hainan Island (Figure 2).

Metals from anthropogenic activities were mostly associated with bioavailable fractions. Additionally, according to a study about metals speciation in Beibu Gulf, $\mathrm{Pb}$ concentrations in bioavailable fractions were higher than in residual fractions, while $\mathrm{Cu}$ and $\mathrm{Cd}$ concentrations in exchangeable and carbonate fractions were relatively higher than other bioavailable fractions [44]. Therefore, we can draw the conclusion that the discharge of terrestrial pollutants was probably from the coastal areas of Guangxi Province or the Pearl River Estuary delivered via the Qiongzhou Strait. Meanwhile, there are some industrial activities around the coastal areas of Guangxi Province, such as coal-fired power plants, mineral mining and metallurgical industry, which can discharge waste into 
aquatic ecosystems [45]. A hotspot of Cd was identified at the center of Beibu Gulf, which was possibly affected by input from Guangxi province or Qiongzhou Strait.

Table 4. Pearson correlation matrix for the metal concentrations and sediment properties.

\begin{tabular}{cccccccccc}
\hline & $\mathbf{C u}$ & $\mathbf{P b}$ & $\mathbf{Z n}$ & $\mathbf{C d}$ & $\mathbf{C r}$ & $\mathbf{O C}$ & Sulfide & Eh & Clay \\
\hline $\mathrm{Cu}$ & 1 & & & & & & & & \\
$\mathrm{~Pb}$ & $0.859^{* *}$ & 1 & & & & & & & \\
$\mathrm{Zn}$ & $0.539^{* *}$ & 0.258 & 1 & & & & & & \\
$\mathrm{Cd}$ & $0.812^{* *}$ & $0.681^{* *}$ & $0.579 * *$ & 1 & & & & \\
$\mathrm{Cr}$ & -0.038 & -0.191 & $0.589^{* *}$ & 0.236 & 1 & & & \\
$\mathrm{OC}$ & 0.153 & 0.096 & -0.111 & 0.013 & -0.173 & 1 & & \\
Sulfide & 0.173 & 0.243 & 0.009 & 0.080 & -0.037 & $0.503 * *$ & 1 & \\
Eh & -0.013 & 0.119 & 0.031 & 0.218 & 0.137 & $-0.441^{*}$ & -0.230 & 1 \\
Clay & $0.390^{*}$ & 0.278 & 0.234 & 0.140 & 0.030 & $0.722^{* *}$ & $0.465^{* *}$ & -0.334 & 1 \\
\hline
\end{tabular}

${ }^{* *}$ Correlation is significant at the 0.01 level (2-tailed). ${ }^{*}$ Correlation is significant at the 0.05 level (2-tailed).

Compared to the above three metals, $\mathrm{Zn}$ and $\mathrm{Cr}$ showed similar spatial distributions in the study area (Figure 2). The highest concentration of $\mathrm{Cr}$ in sediments was at station $J 41(56.47 \mathrm{mg} / \mathrm{kg})$, and the highest concentration for $\mathrm{Zn}$ was at station J07 $(112.25 \mathrm{mg} / \mathrm{kg})$. The high values of heavy metals around the northwest coast of Hainan Island and the Qiongzhou Strait might be related to the river inflow input from the coastal area of Hainan Island, and Qiongzhou Strait. Rivers in the northwest coast of Hainan Island can discharge metals into the Beibu Gulf. For example, Naidu River, the largest river in Hainan Island, discharged sediment detritus into Qiongzhou Strait. The Wenlan River, flowing into the northeast Beibu Gulf, contained high concentrations of metals from industrial sewage, which resulted in higher concentrations of metals at the northwest coast of Hainan Island than in the central Beibu Gulf [46]. Concentrations of $\mathrm{Zn}$ and $\mathrm{Cr}$ increased from the coast to the central areas in the south of the Gulf, which may be influenced by currents from the South China Sea [5].

$\mathrm{Cu}[\mathrm{mg} / \mathrm{kg}] @$ Depth $[\mathrm{m}]=f i r s t$

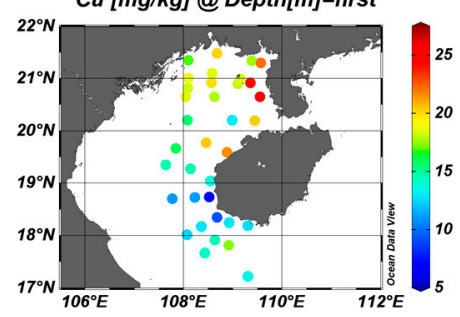

Cd $[\mathrm{mg} / \mathrm{kg}] @$ Depth $[\mathrm{m}]=$ first

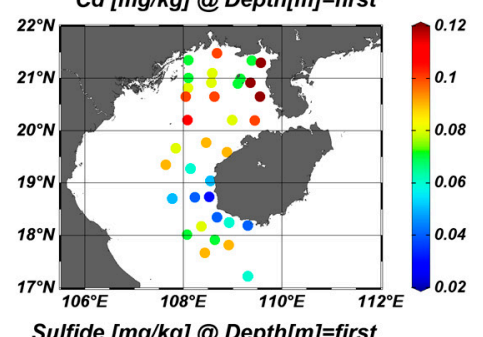

Sulfide $[\mathrm{mg} / \mathrm{kg}] @$ @epth[m]=first

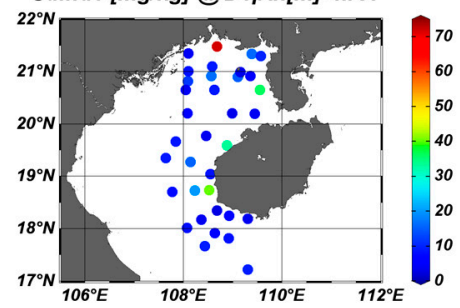

$P b[\mathrm{mg} / \mathrm{kg}] @$ @ Depth[m]=first

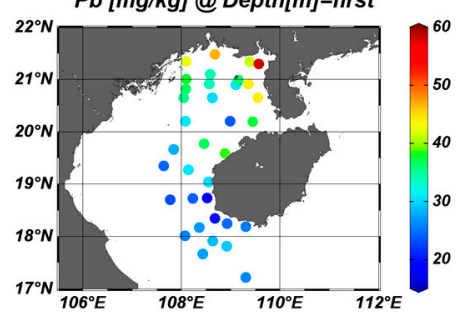

$\operatorname{Cr}[\mathrm{mg} / \mathrm{kg}] @$ Depth[m]=first

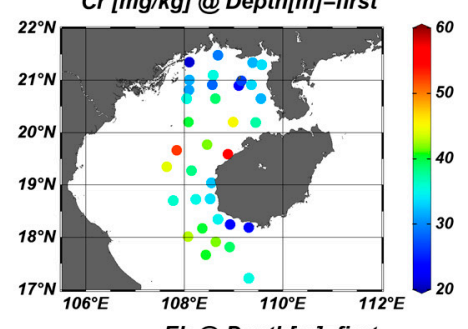

Eh @ Depth[m]=first

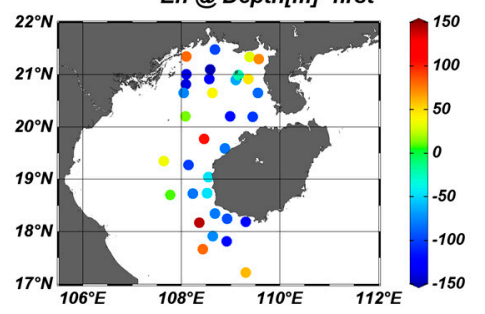

Zn [mg/kg] @ Depth[m]=first

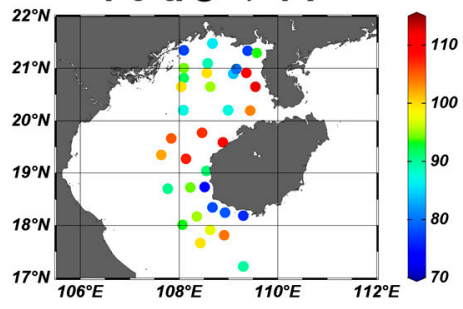

TOC [\%] @ Depth[m]=first

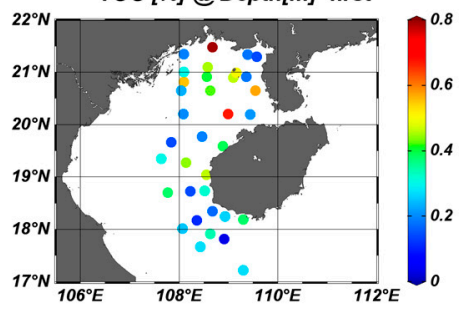

Clay [\%] @ Depth[m]=first

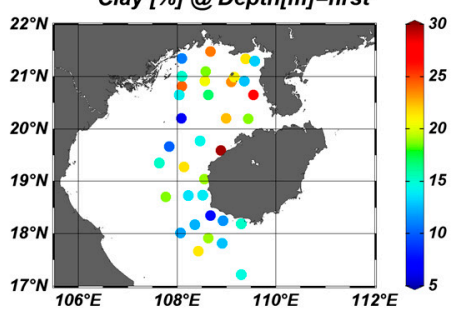

Figure 2. Distribution of heavy metals, total organic carbon (TOC), sulfide, Eh and clay in sediments from the eastern Beibu Gulf. 
However, according to the results of the $\mathrm{I}_{\text {geo }}$, the impacts of anthropogenic activities for increasing $\mathrm{Zn}$ and $\mathrm{Cr}$ were limited compared to natural bedrock. Considerably high concentrations of $\mathrm{Cr}$ were found in the residual fraction which was fairly stable and at a less bioavailable phase [44,47] and therefore indicated the influence of natural bedrock. The relatively high concentrations of $\mathrm{Zn}$ and $\mathrm{Cr}$ in $\mathrm{Fe} / \mathrm{Mn}$ oxide fraction around the Qiongzhou Strait indicated that the diagenetic mobilization of metals and current through the Qiongzhou Strait may affect the distribution [44,48].

\subsection{Cluster and Correlation Analyses}

Hierarchical clustering analysis (HCA) was applied to evaluate the results obtained. The three groups (A, B and C) of sampling stations with different geographical distributions were clearly separated (Figure 3). Clusters A1 and A2 represented the stations off the southwest coast of Hainan Island and the coastal areas of Guangxi province, respectively. A2 may be related to local anthropogenic activities (i.e., discharge of industrial wastewater and municipal sewage, coal combustion and smelting) [45], while A1 was possibly associated with local river input from Hainan Island. Group B contained stations located in the coastal zone of the Leizhou Peninsula, and was represented by stations with higher levels of most metals in the sediments due to the inflow from Pearl River Estuary through the Qiongzhou Strait. All other stations belonged to Group C, which was influenced by various factors such as industry activities, river input or natural bedrock. Results of the HCA showed that sediment samples from different areas had different geochemical behavior and characteristics.

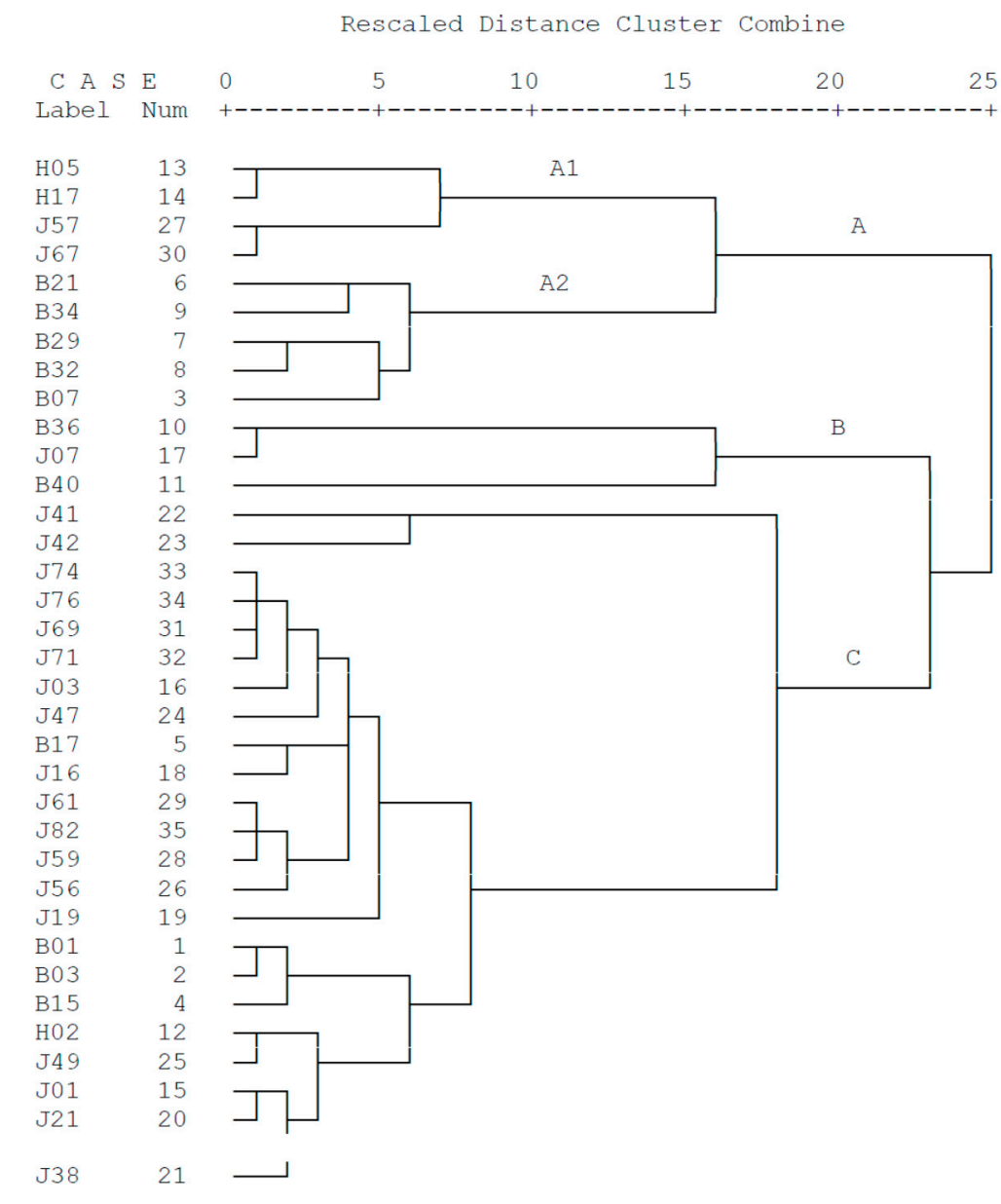

Figure 3. Cluster tree of the sampling stations in the eastern Beibu Gulf.

Table 4 shows the correlation coefficients between heavy metals and some general characteristics of the surface sediments from the eastern Beibu Gulf. A significant positive correlation was found 
between $\mathrm{Cu}$ content and clay, which indicates that clay might be a carrier for $\mathrm{Cu}$ in the marine environment [31]. However, our results also showed that the interrelationships between metals and organic carbon, sulfide or Eh were not significant, indicating that most of the metals are not associated with organic carbon, sulfide or Eh. It was similar to results from Daya Bay [49]. The results showed that the correlation coefficients among $\mathrm{Cu}, \mathrm{Cd}$ and $\mathrm{Pb}$ in the study area $(\mathrm{r}>0.6)$ are significant, which suggested that similar processes governed the behavior of these metals [50]. Combined with the above discussion, these three metals may be from industrial activities. $\mathrm{Zn}$ and $\mathrm{Cr}$ also showed a significant relationship with the natural environment. Overall, our results indicated that the distribution of individual heavy metals in the surface sediments from Beibu Gulf was complex.

\section{Conclusions}

In this study, we found that although the concentrations of $\mathrm{Cu}, \mathrm{Pb}, \mathrm{Zn}, \mathrm{Cd}$ and $\mathrm{Cr}$ in surface sediments were close to the primary standard criterion, the $\mathrm{I}_{\text {geo }}$ results showed that $\mathrm{Pb}$ pollution did exist in this area. Relatively high concentrations of $\mathrm{Cu}, \mathrm{Pb}$ and $\mathrm{Cd}$ were found in the coastal areas of Guangxi Province, Leizhou Peninsula and off the northwest coast of Hainan Island, while high levels of $\mathrm{Zn}$ and $\mathrm{Cr}$ were observed off the northwest coast of Hainan Island. Spatial distribution patterns of these heavy metals show that bioavailable fractions of $\mathrm{Pb}$ were higher than those in the residual fractions, while $\mathrm{Cu}$ and $\mathrm{Cd}$ concentrations in the exchangeable and carbonate fractions were relatively higher than other bioavailable fractions. The diagenetic mobilization of metals and current through the Qiongzhou Strait may affect the distribution of metals. The result of HCA demonstrated three groups of stations. A significant positive correlation was observed between the content of $\mathrm{Cu}$ and clay, and significant correlation coefficients among $\mathrm{Cu}, \mathrm{Cd}$ and $\mathrm{Pb}$ were also found in the study area, indicating that they were controlled by similar processes and had similar behavior. No significant correlations were found between the metals and organic carbon, sulfide or Eh, indicating that these latter factors play minor roles in binding the metals in the sediments.

Acknowledgments: We thank to the crews of research vessel Experiment 2 (South China Sea Institute of Oceanology, Chinese Academy of Sciences) for their performance in the field survey. The cruise was a part of the Chinese Offshore Investigation and Assessment Project (also named: Project 908). This work was supported by the Ocean Public Welfare Scientific Research Projects, the State Oceanic Administration of China (200805095), the National Natural Science Foundation of China (40776040, 40306012, 40776003, 41076133, 41476066 and 41576180), the International Science and technology cooperation project (GASI-IPOVAI-04), the Guangdong Natural Science Foundation of China (2016A030312004), the Natural Science Foundation of Fujian Province (2014J06014), the Basal Research Fund of Xiamen University (2072010507), the Project of Enhancing School with Innovation of Guangdong Ocean University (GDOU2014050201, GDOU2013010203) and the Xiamen University Training Program of Innovation and Entrepreneurship for Undergraduates (2016X0619, 2016X0624, 2016X0629, 103842017050). We gratefully thank Canrong Qiu, Jionghui Sun, Shuiying Huang, Mengyang Liu and Yun Wang for sampling and providing useful information on the data analysis. We are grateful to Professor John Hodgkiss for his assistance with the English.

Author Contributions: All authors contributed to the data assessment and analysis strategy. Fajin Chen coordinated and wrote the main text with contributions from the other co-authors. Jing Lin and Bihua Qian and Tianyao Li contributed to the experiment and measurement. Zhai Wu, Peng Huang, Kai Chen and Minggang Cai contributed to writing the text.

Conflicts of Interest: The authors declare no conflict of interest.

\section{References}

1. Gan, H.Y.; Lin, J.Q.; Liang, K.; Xia, Z. Selected trace metals (As, Cd and Hg) distribution and contamination in the coastal wetland sediment of the northern Beibu Gulf, South China Sea. Mar. Pollut. Bull. 2013, 66, 252-258. [CrossRef] [PubMed]

2. Du, Q.; Zhang, C. Effects of Commercial Clamming on the Survival of Avicennia marina Seedlings in the Beibu Gulf, China. Wetlands 2016, 36, 1047-1053. [CrossRef]

3. Kaiser, D.; Schulz-Bull, D.E.; Waniek, J.J. Profiles and inventories of organic pollutants in sediments from the central Beibu Gulf and its coastal mangroves. Chemosphere 2016, 153, 39-47. [CrossRef] [PubMed] 
4. Zhang, K.; Chen, Z.Z.; Wang, Y.Z.; Sun, D.R.; Qiu, Y.S. Population structure of Priacanthus macracanthus in the Beibu Gulf, and parameters for its growth, mortality and maturity. J. Trop. Oceanogr. 2016, 35, 20-28. (In Chinese)

5. Chen, S.L.; Hu, J.Y.; Qi, Y.Q. Circulation in Beibu Gulf. In China Regional Oceanography; Su, J.L., Ed.; China Ocean Press: Beijing, China, 2011; p. 488, ISBN 978-7-5027-8254-2. (In Chinese)

6. Li, L.; Wang, X.J.; Zhu, A.M.; Yang, G.; Liu, J.H. Assessing metal toxicity in sediments of Yellow River wetland and its surrounding coastal areas, China. Estuar. Coast. Shelf Sci. 2014, 151, 302-309. [CrossRef]

7. Xiong, X.; Tang, Y. The Industrial Development of Beibu Gulf Economic Zone of Guangxi: Issues and Measures. In Proceedings of the Eighth International Conference on Management Science and Engineering Management, Lisbon, Portugal, 25-27 July 2014; Xu, J., Cruz-Machado, V., Lev, B., Nickel, S., Eds.; Springer: Berlin/Heidelberg, Germany, 2014; pp. 1257-1267.

8. Cong, M.; Lü, J.S.; Wu, H.F.; Zhao, J.M. Effect of cadmium on the defense response of Pacific oyster Crassostrea gigas to Listonella anguillarum challenge. Chin. J. Oceanol. Limn. 2013, 31, 1002-1009. [CrossRef]

9. Kishe, M.A.; Machiwa, J.F. Distribution of heavy metals in sediments of Mwanza Gulf of Lake Victoria, Tanzania. Environ. Int. 2003, 28, 619-625. [CrossRef]

10. Marchand, C.; Lallier-Vergès, E.; Baltzer, F.; Albéric, P.; Cossa, D.; Baillif, P. Heavy metals distribution in mangrove sediments along the mobile coastline of French Guiana. Mar. Chem. 2006, 98, 1-17. [CrossRef]

11. Yang, Z.F.; Wang, Y.; Shen, Z.Y.; Niu, J.F.; Tang, Z.W. Distribution and speciation of heavy metals in sediments from the mainstream, tributaries, and lakes of the Yangtze River catchment of Wuhan, China. J. Hazard. Mater. 2009, 166, 1186-1194. [CrossRef] [PubMed]

12. Chen, Z.Y.; Saito, Y.; Kanai, Y.; Wei, T.Y.; Li, L.Q.; Yao, H.S.; Wang, Z.H. Low concentration of heavy metals in the Yangtze estuarine sediments, China: A diluting setting. Estuar. Coast. Shelf Sci. 2004, 60, 91-100. [CrossRef]

13. Huang, D.K.; Du, J.Z.; Zhang, J. Particle dynamics of ${ }^{7} \mathrm{Be},{ }^{210} \mathrm{~Pb}$ and the implications of sedimentation of heavy metals in the Wenjiao/Wenchang and Wanquan River estuaries, Hainan, China. Estuar. Coast. Shelf Sci. 2011, 93, 431-437. [CrossRef]

14. Li, X.D.; Wai, O.W.H.; Li, Y.S.; Coles, B.J.; Ramsey, M.H.; Thornton, I. Heavy metal distribution in sediment profiles of the Pearl River estuary, South China. Appl. Geochem. 2000, 15, 567-581. [CrossRef]

15. Liu, J.H.; Cao, L.; Huang, W.; Zhang, C.T.; Dou, S.Z. Zinc and copper bioaccumulation in fish from Laizhou Bay, the Bohai Sea. Chin. J. Oceanol. Limn. 2014, 32, 491-502. [CrossRef]

16. Xu, Y.H.; Sun, Q.O.; Yi, L.; Yin, X.J.; Wang, A.J.; Li, Y.H.; Chen, J. The source of natural and anthropogenic heavy metals in the sediments of the Minjiang River Estuary (SE China): Implications for historical pollution. Sci. Total Environ. 2014, 493, 729-736. [CrossRef] [PubMed]

17. Pan, K.; Wang, W.X. Trace metal contamination in estuarine and coastal environments in China. Sci. Total Environ. 2012, 421, 3-16. [CrossRef] [PubMed]

18. Gavriil, A.M.; Angelidis, M.O. Metal and organic carbon distribution in water column of a shallow enclosed Bay at the Aegean Sea Archipelago: Kalloni Bay, island of Lesvos, Greece. Estuar. Coast. Shelf Sci. 2005, 64, 200-210. [CrossRef]

19. Zheng, N.; Wang, Q.C.; Liang, Z.Z.; Zheng, D.M. Characterization of heavy metal concentrations in the sediments of three freshwater rivers in Huludao City, Northeast China. Environ. Pollut. 2008, 154, 135-142. [CrossRef] [PubMed]

20. Wu, Z.; Xu, Y.; Cai, M.G.; Cheng, S.Y.; Chen, H.R.; Huang, D.R.; Chen, K.; Lin, Y.; Li, T.Y.; Liu, M.Y.; et al. Metals in Fishes from Yongshu Island, Southern South China Sea: Human Health Risk Assessment. J. Toxicol. 2017, 2017, 1-12. [CrossRef] [PubMed]

21. Tang, D.L.; Kawamura, H.; Lee, M.A.; Van Dien, T. Seasonal and spatial distribution of chlorophyll-a concentrations and water conditions in the Gulf of Tonkin, South China Sea. Remote Sens. Environ. 2003, 85, 475-483. [CrossRef]

22. Ergül, H.A.; Topcuoğlu, S.; Ölmez, E.; Kırbaşoğlu, Ç. Heavy metals in sinking particles and bottom sediments from the eastern Turkish coast of the Black Sea. Estuar. Coast. Shelf Sci. 2008, 78, 396-402. [CrossRef]

23. Wang, Y.Q.; Yang, L.Y.; Kong, L.H.; Liu, E.F.; Wang, L.F.; Zhu, J.R. Spatial distribution, ecological risk assessment and source identification for heavy metals in surface sediments from Dongping Lake, Shandong, East China. Catena 2015, 125, 200-205. [CrossRef] 
24. Yu, R.L.; Yuan, X.; Zhao, Y.H.; Hu, G.R.; Tu, X.L. Heavy metal pollution in intertidal sediments from Quanzhou Bay, China. J. Environ. Sci. 2008, 20, 664-669. [CrossRef]

25. Yang, J.C.; Wang, W.G.; Zhao, M.W.; Chen, B.; Dada, O.A.; Chu, Z.H. Spatial distribution and historical trends of heavy metals in the sediments of petroleum producing regions of the Beibu Gulf, China. Mar. Pollut. Bull. 2015, 91, 87-95. [CrossRef] [PubMed]

26. Chen, Z.Z.; Xu, S.N.; Qiu, Y.S.; Lin, Z.J.; Jia, X.P. Modeling the effects of fishery management and marine protected areas on the Beibu Gulf using spatial ecosystem simulation. Fish. Res. 2009, 100, 222-229. [CrossRef]

27. Cai, M.H.; Lin, J.; Hong, Q.Q.; Wang, Y.; Cai, M.G. Content and distribution of trace metals in surface sediments from the northern Bering Sea, Chukchi Sea and adjacent Arctic areas. Mar. Pollut. Bull. 2011, 63, 523-527. [CrossRef] [PubMed]

28. Müller, G. Schwermetalle in den sedimenten des Rheins-Veränderungen seit 1971. Umschau 1979, 79, 778-783.

29. Li, J.; Gao, J.H.; Wang, Y.P.; Li, Y.; Bai, F.L.; Cees, L. Distribution and dispersal pattern of clay minerals in surface sediments, eastern Beibu Gulf, South China Sea. Acta Oceanol. Sin. 2012, 31, 78-87. [CrossRef]

30. Lian, X.Q.; Wang, Y.F.; Chen, Q.Y. Assessment on heavy metals in sea water, surface sediments and organisms at Guangxi inshore. Mar. Environ. Sci. 2001, 20,59-62. (In Chinese)

31. Ip, C.C.M.; Li, X.D.; Zhang, G.; Wai, O.W.H.; Li, Y.S. Trace metal distribution in sediments of the Pearl River Estuary and the surrounding coastal area, South China. Environ. Pollut. 2007, 147, 311-323. [CrossRef] [PubMed]

32. Niu, H.Y.; Deng, W.J.; Wu, Q.H.; Chen, X.G. Potential toxic risk of heavy metals from sediment of the Pearl River in South China. J. Environ. Sci. 2009, 21, 1053-1058. [CrossRef]

33. Wong, Y.S.; Tam, N.F.Y.; Lau, P.S.; Xue, X.Z. The toxicity of marine sediments in Victoria Harbour, Hong Kong. Mar. Pollut. Bull. 1995, 31, 464-470. [CrossRef]

34. Buccolieri, A.; Buccolieri, G.; Cardellicchio, N.; Dell'Atti, A.; Di Leo, A.; Maci, A. Heavy metals in marine sediments of Taranto Gulf (Ionian Sea, Southern Italy). Mar. Chem. 2006, 99, 227-235. [CrossRef]

35. Christophoridis, C.; Dedepsidis, D.; Fytianos, K. Occurrence and distribution of selected heavy metals in the surface sediments of Thermaikos Gulf, N. Greece. Assessment using pollution indicators. J. Hazard. Mater. 2009, 168, 1082-1091. [CrossRef] [PubMed]

36. Williams, N.; Block, K.A. Spatial and vertical distribution of metals in sediment cores from Río Espíritu Santo estuary, Puerto Rico, United States. Mar. Pollut. Bull. 2015, 100, 445-452. [CrossRef] [PubMed]

37. Lü, D.W.; Zeng, B.; Fang, Y.; Shen, G.; Liu, H.J. Distribution and pollution assessment of trace metals in seawater and sediment in Laizhou Bay. Chin. J. Oceanol. Limn. 2015, 33, 1053-1061. [CrossRef]

38. Xu, G.; Liu, J.; Pei, S.F.; Gao, M.S.; Hu, G.; Kong, X.H. Sediment properties and trace metal pollution assessment in surface sediments of the Laizhou Bay, China. Environ. Sci. Pollut. Res. 2015, 22, 11634-11647. [CrossRef] [PubMed]

39. Gu, Y.G.; Lin, Q.; Yu, Z.L.; Wang, X.N.; Ke, C.L.; Ning, J.J. Speciation and risk of heavy metals in sediments and human health implications of heavy metals in edible nekton in Beibu Gulf, China: A case study of Qinzhou Bay. Mar. Pollut. Bull. 2015, 101, 852-859. [CrossRef] [PubMed]

40. Förstner, U.; Wittmann, G.T.W. Metal Pollution Assessment from Sediment Analysis. In Metal Pollution in the Aquatic Environment, 2nd ed.; Goldberg, E.D., Ed.; Springer: Berlin/Heidelberg, Germany, 1981; pp. 110-196, ISBN 978-3-540-12856-4.

41. Müller, G. Die Schwermetallbelastung der sedimente des Neckara und seiner Nebenflüsse: Eine Bestandsaufnahme. Chemiker-Zeitung 1981, 105, 157-164. (In German)

42. Dou, Y.G.; Li, J.; Zhao, J.T.; Hu, B.Q.; Yang, S.Y. Distribution, enrichment and source of heavy metals in surface sediments of the eastern Beibu Bay, South China Sea. Mar. Pollut. Bull. 2013, 67, 137-145. [CrossRef] [PubMed]

43. Dou, Y.G.; Li, J.; Li, Y. Rare earth element compositions and provenance implication of surface sediments in the eastern Beibu Gulf. Geochimica 2012, 41, 147-157. (In Chinese)

44. Ma, Z.K. Study on Speciation and Distribution of Heavy Metal in the Sediments from the Northern Beibu Gulf, China. Master's Thesis, Xiamen University, Xiamen, China, 2009; p. 81. (In Chinese)

45. Zhong, C.; Yang, Z.F.; Jiang, W.; Hu, B.Q.; Hou, Q.Y.; Yu, T.; Li, J. Ecological geochemical assessment and source identification of trace elements in atmospheric deposition of an emerging industrial area: Beibu Gulf economic zone. Sci. Total Environ. 2016, 573, 1519-1526. [CrossRef] [PubMed] 
46. Zhao, D.B.; Wan, S.M.; Yu, Z.J.; Huang, J. Distribution, enrichment and sources of heavy metals in surface sediments of Hainan Island rivers, China. Environ. Earth Sci. 2015, 74, 5097-5110. [CrossRef]

47. Sarkar, S.K.; Favas, P.J.C.; Rakshit, D.; Satpathy, K.K. Geochemical speciation and risk assessment of heavy metals in soils and sediments. In Environmental Risk Assessment of Soil Contamination; Hernandez-Soriano, M.C., Ed.; InTech: London, UK, 2014; p. 918.

48. Fernandes, M.C.; Nayak, G.N. Speciation of metals and their distribution in tropical estuarine mudflat sediments, southwest coast of India. Ecotoxicol. Environ. Saf. 2015, 122, 68-75. [CrossRef] [PubMed]

49. Neto, J.A.B.; Gingele, F.X.; Leipe, T.; Brehme, I. Spatial distribution of heavy metals in surficial sediments from Guanabara Bay: Rio de Janeiro, Brazil. Environ. Geol. 2006, 49, 1051-1063. [CrossRef]

50. Qiu, Y.W.; Yan, W.; Wang, Z.D.; Zhang, G. Distributions of heavy metals in seawater, sediments and organisms at Daya Bay and their ecological harm. J. Trop. Oceanogr. 2005, 24, 69-76. (In Chinese)

(C) 2018 by the authors. Licensee MDPI, Basel, Switzerland. This article is an open access article distributed under the terms and conditions of the Creative Commons Attribution (CC BY) license (http://creativecommons.org/licenses/by/4.0/). 